\title{
Vorwort / Foreword
}

Die 35. Hauptversammlung der Deutschen Quartärvereinigung DEUQUA fand in der Zeit vom 13.-17. September mit mehr als 180 Teilnehmern aus 16 Ländern in Greifswald statt. Sie stand unter dem Motto „Gletscher, Wasser, Mensch - quartärer Landschaftswandel im peribaltischen Raum" und wurde gemeinsam mit der 12. Jahrestagung der INQUA PeriBaltic Working Group veranstaltet. In elf Vortragsblöcken, die klassische Themen der Quartärforschung wie Glazial- und Periglazialmorphologie, Küsten- und Schelfgeologie sowie Geochronologie und Stratigraphie abdeckten, andererseits aber auch neuen Schwerpunkten wie Georisiken Platz einräumten, wurde die große Bandbreite der Interessen der in DEUQUA und PeriBaltic Working Group organisierten Fachleute deutlich.

Der regionale Kenntnisstand zum Quartär Nordostdeutschlands wurde auf sieben Exkursionen entlang der Ostseeküste und ins Binnenland eindrucksvoll demonstriert. Das als Band 1 der Reihe DEUQUA Exkursionsführer anlässlich der Tagung erschienene Heft "Eiszeitlandschaften in Mecklenburg-Vorpommern" kann kostenlos als eBook beim Verlag Geozon Science Media (http://www. geozon.info/publikationen) heruntergeladen oder als gedruckte Fassung für 34,00 € bestellt werden. Mögen weitere (tagungsbegleitende) Exkursionsführer in dieser Reihe folgen!

Sieben Beiträge, die auf der Tagung präsentiert wurden, umfasst der aktuelle Band des E \& G Quaternary Science Journal. Thematisch breit gefächert wie die Tagung, werden neue Ergebnisse zur Terrassenstratigraphie des Lech (Gesslein \& Schellmann, Schielein et al.), zur Genese von Eskern (GRUBE) und Stauchendmoränen (LUDwIG), zur spätglazial-holozänen Landschaftsentwicklung (KossLeR \& STRAHL) und der geomorphologischen Reaktion auf den Landnutzungswandel (KüSTER et al.) sowie zu mittelweichselzeitlichen Interglazialablagerung in N-Finnland (SARALA \& EsKoLA) vorgestellt und diskutiert. Die Herausgeber wünschen den Beiträgen eine interessierte Aufnahme und Diskussion in der Fachwelt.

Abschließend sei den Studenten und Mitarbeitern der Universität Greifswald sowie den Kollegen in Landesverwaltungen und Praxis herzlich für die gemeinsame Organisation und Durchführung der Tagung und Exkursionen gedankt. Unser Dank gilt desweiteren den Sponsoren, deren Unterstützung maßgeblich half, die Tagungs- und Publikationskosten zu tragen, sowie den Autoren, den Gutachtern und dem Verlag geozon, die alle zur Entstehung des vorliegendes Bandes beigetragen haben.
From the $13^{\text {th }}-17^{\text {th }}$ September 2010 the $35^{\text {th }}$ biannual conference of the German Quaternary Association DEUQUA took place in Greifswald attended by more than 180 participants representing 16 countries. The meeting was held jointly with the 12th annual conference of the INQUA Peribaltic Working Group and was titled „Ice, water, humans - Quaternary landscape evolution in the PeriBaltic Region”. Eleven sessions covering a variety of Quaternary research subjects such as glacial and periglacial morphology, coastal and shelf geology as well as geochronology and stratigraphy were held. These classical research fields were supplemented by newer research initiatives such as geohazards, together representing the big range of interests within the DEUQUA and the PeriBaltic Working Groups.

The conference included seven field trips along the Baltic Sea coast and adjacent areas which introduced the current understanding of regional Quaternary processes. On the occasion of the meeting a detailed field guide titled "Eiszeitlandschaften in Mecklenburg-Vorpommern" was published (available at no cost under http://www.geozon. info/publikationen or as a printed hardcopy at your local bookstore for $34 €$ ). This publication is the first issue of the new DEUQUA-field-guide-series, may there be many more editions in the future!

The presented volume of the E \& G Quaternary Science Journal contains seven papers which were presented at the conference. They include a wide range of new results dealing with the stratigraphy of the River Lech terraces (GESSLEIN \& Schellmann, Schielein et al.), esker genesis (GruBE), push moraines (LuDwiG), Late glacial and Holocene landscape development of Rügen Island (KossLER \& STRAHL et al.), geomorphological responses to land use changes (KüsTER et al.), and mid-Weichselian interstadial deposits in N Finland (SARALA \& EsKola). We hope that these research articles will stimulate fruitful further discussion among experts working in these fields.

We would like to express our sincere thanks to colleagues and students of the University of Greifswald and cooperating state government offices as well as participating companies for the joint organization and implementation of the conference. Several sponsors helped to finance this international meeting and its related publications. Finally we would like to thank all authors, reviewers and the Geozon Publishing House who helped to create this volume.

REINHARD LAMPE

SEBASTIAN LORENZ 